\title{
Correction to: LncRNA NEAT1 mediates progression of oral squamous cell carcinoma via VEGF-A and Notch signaling pathway
}

\author{
Ke He ${ }^{1}$, Zhi-Bin Zhu', Rui Shu ${ }^{2 *}$ and Ai Hong ${ }^{3}$
}

\section{Correction to: World J Surg Onc 18, 261 (2020) \\ https://doi.org/10.1186/s12957-020-02028-x}

Following publication of the original article [1], the authors identified an error in the first author name.

The incorrect author name is: $\mathrm{He} \mathrm{Ke}$

The correct author name is: $\mathrm{Ke} \mathrm{He}$

The author group has been updated above and the original article [1] has been corrected.

\footnotetext{
Author details

'Department of Stomatology, Chengdu Seventh People's Hospital, Chengdu 610015, Sichuan, China. ${ }^{2}$ Department of Orthodontics and Pediatric Dentistry, West China School of Stomatology State Key Laboratory of Oral Diseases, Sichuan University, Chengdu 610041, China. ${ }^{3}$ Department of Stomatology, The Third Affiliated Hospital of Sun Yat-sen University, Guangzhou 510000, China.
}

Published online: 27 October 2020

\section{Reference}

1. He K, Zhu Z, Shu R, Hong A. LncRNA NEAT1 mediates progression of oral squamous cell carcinoma via VEGF-A and Notch signaling pathway. World J Surg Onc. 2020;18:261. https://doi.org/10.1186/s12957-020-02028-x.

\footnotetext{
The original article can be found online at https://doi.org/10.1186/s12957020-02028-x

*Correspondence: vbcy4557@126.com; shuruispecial@163.com

${ }^{2}$ Department of Orthodontics and Pediatric Dentistry, West China School of

Stomatology State Key Laboratory of Oral Diseases, Sichuan University,

Chengdu 610041, China

Full list of author information is available at the end of the article
}

(c) The Author(s). 2020 Open Access This article is licensed under a Creative Commons Attribution 4.0 International License, which permits use, sharing, adaptation, distribution and reproduction in any medium or format, as long as you give appropriate credit to the original author(s) and the source, provide a link to the Creative Commons licence, and indicate if changes were made. The images or other third party material in this article are included in the article's Creative Commons licence, unless indicated otherwise in a credit line to the material. If material is not included in the article's Creative Commons licence and your intended use is not permitted by statutory regulation or exceeds the permitted use, you will need to obtain permission directly from the copyright holder. To view a copy of this licence, visit http://creativecommons.org/licenses/by/4.0/ The Creative Commons Public Domain Dedication waiver (http://creativecommons.org/publicdomain/zero/1.0/) applies to the data made available in this article, unless otherwise stated in a credit line to the data. 